\title{
EDITORIAL
}

\section{Enfermagem e estrutura social}

Acabo de receber da enfermeira Maria Ivete Ribeiro de Oliveira, excelente trabalho sobre "Enfermagem e Estrutura Social" apresentado ao XXXI Congresso Brasileiro de Enfermagem, realizado recentemente em Fortaleza (Ceará).

A Enfermagem Brasileira vem crescendo de maneira a se tornar profissão altamente qualificada, servindo com grande nobreza de propósitos a todos aqueles que dela necessitam. Com outros elementos da área de saúde ela serve aos anseios da sociedade a que se integra, provendo e zelando pela manutenção do bem-estar físico, mental e social do indivíduo e da coletividade a que ela serve.

A Enfermagem, como a Medicina, tem um passado estóico, heróico e cristão, vivendo de ricas tradições que devem ser preservadas, estabelecidas pelo gênio de Florence Nightingale.

São múltiplas, nos dias de hoje as atividades da enfermeira, aliviando o sofrimento físico dos doentes, dando-lhes assistência espiritual, zelando pela manutenção da ordem e da moral dos que lhe são subordinados, praticando o treinamento sistemático no período de noviciado àquelas que se preparam para o exercício de tão nobre profissão. Exercem, também, a Enfermagem Comunitária, assistem os pacientes nos centros cirúrgicos e obstétricos, colaboram nos serviços de planejamento de saúde, administram setores importantes em hospitais privados ou de ensino, visando no momento a saúde da coletividade ampliando, assim, o campo de suas atividades.

Criado o "Sistema Nacional de Saúde", a cargo de diferentes órgãos, as enfermeiras passarão a desempenhar papel dos mais importantes na promoção da saúde e prevenção das doenças, contribuindo também para a reabilitação dos pacientes, numa abordagem que virá engrandecer a Enfermagem, considerada como a Ciência e a Arte da Humanidade.

Hoje em dia as Escolas de Enfermagem já preparam seus docentes, espalhados pelas várias regiões geográficas do País, servindo a seus semelhantes, num atendimento que merece por parte do Estado um posicionamento mais efetivo em relação às suas justas reivindicações.

Velhos esquemas profissionais têm que ser refeitos, buscando-se a excelência da prática profissional, redimensionando as experiências de aprendizagem para que, face à nova estrutura social que o País atravessa, possam as enfermeiras sair do conformismo da submissão, desafiando os problemas que deverão enfrentar, mobilizando setores influentes da comunidade brasileira, para mostrar-lhes o que a Enfermagem poderá oferecer numa missão patriótica, aos programas de saúde do País. 